\title{
Muatan penalaran dan pembuktian matematis pada buku teks matematika SMA kelas X Kurikulum 2013
}

\author{
Tria Utari ${ }^{1} *$, Hartono Hartono ${ }^{2}$ \\ ${ }^{1}$ SMA Negeri 1 Kepahiang. Jalan Pasar Ujung, Kelurahan Pasar Ujung, Kepahiang, Bengkulu, 39372, Indonesia \\ ${ }^{2}$ Program Studi Pendidikan Matematika, Program Pascasarjana, Universitas Negeri Yogyakarta. \\ Jalan Colombo No. 1, Karangmalang, Yogyakarta 55281, Indonesia. \\ ${ }^{1}$ tria.utari.tu@gmail.com, ${ }^{2}$ hartono@uny.ac.id \\ * Corresponding Author
}

\section{ARTICLE INFO}

\section{Article history}

Received: 23 Nov. 2017;

Revised: 27 May 2019;

Accepted: 28 May 2019

\section{Keywords}

analisis isi; penalaran matematis; pembuktian matematis; buku teks; content analysis; mathematical reasoning proof; textbook

\section{ABSTRACT}

Penelitian ini bertujuan untuk mendeskripsikan muatan penalaran dan pembuktian matematis pada buku teks matematika SMA kelas X Kurikulum 2013. Penelitian ini menggunakan pendekatan kualitatif deskriptif jenis analisis isi. Sumber data penelitian adalah buku teks Matematika kelas X Kurikulum 2013 edisi revisi 2016 yang diterbitkan oleh Pusat Kurikulum dan Perbukuan Balitbang Kementerian Pendidikan dan Kebudayaan Republik Indonesia. Teknik pengumpulan data dalam penelitian ini adalah pembacaan dan pencatatan dengan menggunakan instrumen yang telah divalidasi berupa pedoman analisis dokumen. Data penelitian dianalisis menggunakan skema Kripendorff yang meliputi pengumpulan data, penentuan sampel, perekaman/pencatatan, reduksi, penarikan kesimpulan dan narasi. Hasil penelitian menunjukkan bahwa pada bagian materi, siswa memiliki kesempatan yang besar untuk menalar dan membuktikan melalui membaca justifikasi namun memiliki kesempatan yang kecil melalui pengembangan justifikasi. Pada soal evaluasi, siswa belum memiliki kesempatan untuk menalar dan membuktikan melalui pengerjaan soal dengan indikator mengevaluasi argumen. Artinya, buku teks belum sepenuhnya memberikan kesempatan bagi siswa untuk belajar menalar dan membuktikan.

This study aimed to describe the content of mathematical reasoning and proof in the high school mathematics textbooks $10^{\text {th }}$ grade Curriculum 2013. This research used descriptive qualitative approach type of content analysis. The source of research data was the high school mathematics textbook of $10^{\text {th }}$ grade Curriculum 2013 edition of revision 2016 published by Ministry of Education and Culture of the Republic of Indonesia. Data collection techniques in this study was the reading and recording using instruments that had been validated in the form of document analysis guidelines. Research data was analyzed using Kripendorff scheme which included unitizing, sampling, recording/coding, reducing, inferring and narrating. The results showed that in the learning material section students had big opportunities to learn reasoning and proof through justification reading, but they had small opportunities in justification developing. In evaluation section, students had not opportunities to learn reasoning and proof through argument evaluation problem solving. Therefore, the textbook had not fully provided opportunities for students to learn reasoning and proof.

This is an open access article under the CC-BY-SA license.

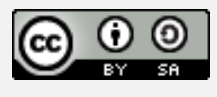

How to Cite: Utari, T., \& Hartono, H. (2019). Muatan penalaran dan pembuktian matematis pada buku teks matematika SMA kelas X Kurikulum 2013. Jurnal Riset Pendidikan Matematika, 6(1), 1-13. doi:https://doi.org/10.21831/jrpm.v6i1.17002 


\section{Jurnal Riset Pendidikan Matematika, 6 (1), 2019 - 2}

Tria Utari, Hartono Hartono

\section{PENDAHULUAN}

Penalaran dan pembuktian merupakan kemampuan yang penting dalam mempelajari matematika. National Council of Teachers of Mathematics (National Council of Teacher of Mathematics, 2009, p. 1) menyatakan bahwa pelajaran matematika SMA yang berdasarkan pada penalaran akan mempersiapkan siswa dalam kehidupan masyarakat, dunia kerja, maupun studi lanjut. Sebaliknya, matematika sangat memungkinkan untuk dapat meningkatkan kemampuan penalaran (Wibowo, 2017, p.1). Inilah mengapa kegiatan menalar harus menjadi bagian dari pembelajaran matematika setiap harinya. Hal ini juga didukung oleh pendapat Ontario (2005, p. 17) bahwa proses penalaran mendukung pemahaman dalam belajar matematika dan memungkinkan siswa untuk memahami matematika yang mereka pelajari.

Dalam Peraturan Menteri Pendidikan dan Kebudayaan Republik Indonesia Nomor 21 tahun 2016 tentang standar isi pendidikan dasar dan menengah dijelaskan bahwa salah satu kompetensi yang harus dimiliki siswa dalam pembelajaran matematika yakni menjelaskan pola dan menggunakannya untuk memprediksi kecenderungan (trend) atau memeriksa kesahihan argument (Menteri Pendidikan dan Kebudayaan Republik Indonesia, 2016). Hal ini merupakan kegiatan penalaran dan pembuktian. Sebagai mana dijelaskan dengan rinci oleh Stylianides dan Stylianides (2006, p. 202) bahwa penalaran dan pembuktian menggambarkan aktivitas menyeluruh yang mencakup menggeneralisasi pola, membuat konjektur, memberikan argumen dan mengembangkan bukti.

Penalaran menjadi salah satu kompetensi penting dalam Kurikulum 2013 (Fithriyyati \& Maryani, 2018). Kurikulum 2013 menekankan secara tersirat penalaran sebagai bagian dari kompetensi yang harus dicapai siswa dalam pembelajaran matematika. Dalam Peraturan Menteri Pendidikan dan Kebudayaan Republik Indonesia Nomor No. 21 Tahun 2016 tentang Standar isi pendidikan dasar dan menengah dijelaskan bahwa salah satu kompetensi yang harus dimiliki siswa dalam pembelajaran matematika yakni menunjukkan sikap logis (Menteri Pendidikan dan Kebudayaan Republik Indonesia, 2016). Sikap logis dapat dikatakan sebagai kegiatan penalaran. Hal ini didukung oleh pernyataan Van de Walle (2007, p. 5) bahwa penalaran adalah pemikiran logis yang membantu kita dalam memutuskan apakah dan mengapa jawaban kita masuk akal. Secara tersurat, dalam Peraturan Menteri Pendidikan dan Kebudayaan Republik Indonesia nomor 21 Tahun 2016 tentang Standar isi Pendidikan Dasar dan Menengah dikatakan bahwa dalam domain keterampilan, siswa diharapkan menujukkan keterampilan menalar (Menteri Pendidikan dan Kebudayaan Republik Indonesia, 2016).

Pada kenyataannya, siswa di Indonesia masih memiliki kemampuan penalaran yang rendah. Hal ini ditunjukkan dari hasil penelitian Programme for International Student Assessment (PISA) yang berfokus pada penelitian tentang kemampuan literasi matematis. Organization for Economic Cooperation and Development (OECD) (2013, p. 17) mendefinisikan literasi matematis sebagai suatu kapasitas individu dalam memformulasikan, menggunakan dan menafsirkan matematika dalamberbagai konteks, termasuk didalammnya penalaran secara matematis. PISA membagi tingkatan keahlian dalam matematika ke dalam enam level. Level diurutkan berdasarkan skor yang diperoleh suatu negara pada uji yang dilaksanakan oleh PISA. Siswa dikatakan telah memiliki kemampuan menalar jika skornya berada pada level tiga hingga enam. Hasil PISA menunjukkan bahwa pada tahun 2012, Indonesia meraih skor 375 yang menunjukkan bahwa Indonesia berada pada level satu. Artinya, siswa Indonesia bisa dikatakan belum memiliki kemampuan penalaran yang baik. Pada level ini siswa hanya dapat menjawab soal yang termasuk konteks familiar dimana semua informasi yang relevan disajikan dan pertanyaan didefinisikan secara jelas (OECD, 2014, p.61).

Disamping itu, banyak siswa SMA mengalami kesulitan dalam mengkonstruksikan dan memahami pembuktian. Thompson, Senk dan Johnson (2012, p.254) menyatakan bahwa siswa tidak memahami makna atau tujuan pembuktian, tidak bisa membedakan contoh empiris yang terbukti atau tidak terbukti, kekurang pengetahuan tentang konsep, definisi, notasi dan tidak familiar dengan strategi pembuktian, termasuk bagaimana memulai pembuktian, dan strategi metakognitif untuk mengamati kemajuannya ketika sedang melakukan pembuktian. Reiss, Heinze, Renkl dan Grob (2008, p.455) menyatakan bahwa banyak siswa menghadapi kesulitan yang serius dalam penalaran konsisten dan berargumentasi, khususnya pada pembuktian matematis.

Kemampuan penalaran dan pembuktian matematis siswa tentunya dipengaruhi oleh proses pembelajaran dan bahan ajar yang digunakan. Salah satu bahan ajar yang digunakan dalam pembelajaran yaitu buku teks. Pada Peraturan Menteri Pendidikan Nasional Nomor 11 Tahun 2005 dikatakan bahwa 


\section{Jurnal Riset Pendidikan Matematika, 6 (1), 2019 - 3}

Tria Utari, Hartono Hartono

buku teks pelajaran digunakan sebagai acuan wajib oleh guru dan peserta didik dalam proses pembelajaran (Menteri Pendidikan Nasional Republik Indonesia, 2005). Pada Peraturan Menteri Pendidikan dan Kebudayaan Republik Indonesia No. 8 Tahun 2016 dinyatakan bahwa buku yang digunakan oleh satuan pendidikan, baik berupa buku teks pelajaran maupun buku non-teks pelajaran, merupakan sarana proses pembelajaran bagi guru dan peserta didik (Menteri Pendidikan dan Kebudayaan Republik Indonesia, 2016). Begle menyatakan bahwa kebanyakan pembelajaran siswa diarahkan oleh buku dibandingkan oleh guru (Thompson, Senk \& Johnson, 2012, p.254). Buku berfungsi sebagai fasilitator yang mampu membantu siswa belajar mandiri mengembangkan kemampuannya termasuk mengembangkan kemampuan penalaran siswa.

Analisis muatan penalaran dan pembuktian matematis pada buku teks sebelumnya telah pernah dilakukan oleh beberapa peneliti. Thompson, Senk dan Johnson melakukan penelitian pada tahun 2012 di Amerika. Penelitian yang serupa juga pernah dilakukan oleh Stacey dan Vincent pada tahun 2009 di Australia. Sedangkan, penelitian ini belum pernah dilakukan di Indonesia. Banyak peneliti yang menganalisis buku teks pelajaran matematika di Indonesia, namun belum ada yang berfokus pada muatan penalaran dan pembuktian matematis. Sebagai contoh, Widyaharti, Trapsilasiwi dan Fatahillah (2015) menganalisis buku siswa matematika Kurikulum 2013 untuk kelas X berdasarkan rumusan Kurikulum 2013.

Siswa sekolah menengah atas hendaknya memiliki kemampuan yang baik dalam matematika (Habsah, 2017, p.43). Penelitian yang akan dilakukan ini berfokus pada buku teks pelajaran kelas X SMA dikarenakan untuk memperhatikan kebutuhan siswa yang sedang berada pada tahap operasi formal. Sebagaimana menurut Piaget, tahap operasi formal terjadi pada anak berusia sebelas sampai lima belas tahun, dimana pada tahap ini anak-anak kini bisa menangani situasi hipotesis dan proses berpikir mereka tak lagi tergantung hanya pada hal-hal yang langsung dan riil, pemikiran pada tahap ini semakin logis (Olson \& Hergenhahn, 2012, p.320). Artinya, siswa kelas X yang rata-rata berumur empat belas sampai lima belas tahun telah mencapai tahap dimana mereka perlu menggali kemampuan penalaran dan pembuktian mereka. Hal ini penting untuk menjadi perhatian agar mereka siap dari awal masa SMA untuk menghadapi tantangan di tingkat berikutnya hingga ke masyarakat.

Secara khusus, Pusat Perbukuan Departemen Pendidikan Nasional (2005, p.7) menyatakan bahwa buku teks pelajaran matematika hendaknya memenuhi tiga aspek standar, yakni aspek materi, penyajian dan bahasa. Pusat Perbukuan Departemen Pendidikan Nasional (2005, p.7) menjelaskan lebih rinci standar-standar yang dipandang berkaitan dengan materi, terdapat sepuluh sub aspek yakni (1) kelengkapan materi; (2) akurasi; (3) penalaran (reasoning) dan pembuktian; (4) problem solving; (5) komunikasi; (6) koneksi (keterkaitan); (7) menggunakan gambar, tabel, rumus, cerita, grafik, atau ilustrasi; (8) tugas-tugas (task) dan soal-soal; (9) materi tidak tumpang tindih; dan (10) soal-soal kontekstual. Pada penelitian ini, fokus analisis hanya pada sub aspek penalaran (reasoning) dan pembuktian.

Pusat Perbukuan Departemen Pendidikan Nasional (2005, p.10) menyatakan bahwa siswa memerlukan kemampuan penalaran (reasoning) dan pembuktian dalam menarik kesimpulan dalam menguji kebenaran jawaban-jawaban suatu permasalahan. Pusat Perbukuan Departemen Pendidikan Nasional (2005, p.34) juga menjelaskan indikator dari sub aspek pada aspek materi, untuk sub aspek penalaran dan pembuktian, hendaknya materi disajikan secara runtut (tahap demi tahap) dan kesimpulan diambil dari fakta atau data sebelumnya.

National Council of Teacher of Mathematics (2000, p.56) menuliskan standar proses yang harus dilalui siswa agar mampu mengembangkan kemampuan penalaran dan pembuktian, yakni: (1) mengenali penalaran dan pembuktian sebagai aspek dasar dari matematika; (2) membuat dan menyelidiki konjektur matematika; (3) mengembangkan dan mengevaluasi pernyataan dan bukti matematika; (4) memilih dan menggunakan berbagai jenis penalaran dan metode pembuktian. Penelitian ini kemudian menggunakan standar proses yang dibuat oleh NCTM untuk menjadi pedoman dalam penggunaan kerangka analisis. Artinya, penelitian ini menggunakan istilah "penalaran dan pembuktian matematis" sebagai satu kesatuan untuk menggambarkan kegiatan penalaran yang berfokus pada kegiatan pembuktian.

Terdapat beberapa kegiatan dalam pembuktian matematis. Mejia-Ramos menyatakan bahwa terdapat tiga aktivitas argumentatif utama terkait pembuktian, yakni constructing a novel argument, presenting an available argument, and reading a given argument (Weber \& Mejia-Ramos, 2011, p. 331). Osterholm (2005, p.325) menyatakan bahwa aktivitas membaca dan memahami bacaan memiliki 


\section{Jurnal Riset Pendidikan Matematika, 6 (1), 2019 - 4}

Tria Utari, Hartono Hartono

peran penting dalam pendidikan matematika. Membaca dan memahami bacaan juga merupakan bagian dari kegiatan penalaran dan pembuktian matematis. Mejia Ramos (Weber \& Mejia-Ramos, 2011, p. 331) menjelasakan bahwa pemahaman terhadap suatu argumen dapat terjadi ketika siswa membaca bukti di dalam buku teks.

Mejia-Ramos membedakan kegiatan membaca argumen menjadi dua kegiatan, yakni memahami dan mengevaluasi suatu pernyataan (Weber \& Mejia-Ramos, 2011, p. 331). Senada dengan kegiatan justifikasi meliputi pemeriksaan justifikasi yang diberikan atau menyediakan justifikasi dari suatu pernyataan (OECD, 2015). Artinya, buku teks perlu memuat argumen ataupun justifikasi yang menjadi bahan bacaan siswa dalam rangka memfasilitasi siswa dalam mengasa kemampuan penalaran dan pembuktian matematis.

Argumen yang perlu dimuat dalam buku teks sebagai bahan bacaan dapat berupa argumen umum maupun argumen khusus. Movshovitz Hadar dalam Thompson, Senk dan Johnson, (2012, p. 282) menjelaskan bahwa penalaran tentang kasus khusus merupakan langkah pedagogis yang membantu menyimpulkan argumen umum. Penyajian sifat atau konjektur yang dijustifikasi baik dengan argumen umum maupun argumen khusus memberikan kesempatan bagi siswa untuk membaca dan memahami pembuktian matematis.

Untuk menyelidiki kebenaran suatu konjektur, siswa dapat menggunakan contoh penyangkal. Shumway \& Lester (1974, p. 210) menyimpulkan dari hasil penelitiannya bahwa negative instances are important in the learning of concepts. Dari penjelasan Shumway \& Lester (1974) kita dapat memahami bahwa siswa perlu memahami baik contoh yang benar maupun yang salah dalam mempelajari suatu konsep. Hal ini juga bermanfaat bagi siswa dalam menyelidiki konjektur. Standar proses yang dikemukakan NCTM belum mengarahkan secara jelas pada proses penggunaan contoh penyangkal. Itulah mengapa hal ini perlu ditambahkan sebagai konten yang perlu diamati dalam buku teks.

Penjelasan tersebut menjadi landasan bahwa buku teks hendaknya memuat bahan bacaan yang memberikan kesempatan bagi siswa untuk mengembangkan kemampuan penalaran dan pembuktian matematis. Bahan bacaan tersebut dapat berupa argumen atau justifikasi. Letak yang sesuai bagi bahan bacaan ini di dalam buku teks adalah pada bagian materi pembelajaran. Selanjutnya, buku teks hendaknya memuat konten yang mendukung standar proses penalaran dan pembuktian matematis. Letak yang sesuai bagi konten ini di dalam buku teks adalah pada bagian soal evaluasi.

Berdasarkan teori yang telah dijabarkan, peneliti menemukan suatu kerangka kerja penelitian sebelumnya yang sangat relevan dengan penelitian ini, yakni kerangka kerja yang dibuat oleh Thompson, Senk dan Johnson (2012) yang digunakan dalam penelitian mereka. Thompson, Senk dan Johnson (2012, p.258) membuat kerangka kerja yang menjadi pedoman untuk menganalisis muatan penalaran dan pembuktian dalam buku teks yang terdiri dari kode-kode untuk melihat muatan tersebut dalam buku teks baik pada bagian materi maupun latihan. Kerangka kerja untuk bagian materi dibuat untuk melihat apakah terdapat kesempatan bagi siswa untuk membuat atau menyelidiki suatu konjektur dan apakah suatu pernyataan yang digunakan untuk membuktikan konjektur, sifat, atau teorema tersedia untuk digunakan guru dalam mengajar atau dibaca siswa.

Thompson, Senk dan Johnson (2012, pp.261-262) membuat empat indikator muatan penalaran dan pembuktian untuk menganalisis materi dalam buku, yakni: (1) sifat-sifat dijustifikasi dengan sebuah bukti; (2) sifat-sifat dijustifikasi menggunakan suatu argumen deduktif berdasarkan kasus khusus; (3) Justifikasi sifat-sifat menajadi tugas untuk dikerjakan siswa; (4) tidak ada justifikasi yang disediakan dan tidak ada pesan bahwa siswa diminta untuk melakukan justifikasi. Sementara, tiga indikator umum dibuat untuk menganalisis muatan penalaran dan pembuktian dalam latihan, yakni: (1) membuat atau menyelidiki konjektur; (2) mengembangkan atau mengevaluasi suatu argumen; (3) indikator penalaran dan pembuktian lainnya (memberikan contoh penyangkal, memperbaiki atau mengidentifikasi suatu kesalahan, menerapkan prinsip pembuktian).

Berdasarkan permasalahan yang telah dikemukakkan peneliti ingin mendeskripsikan muatan penalaran dan pembuktian matematis pada buku teks matematika SMA kelas X Kurikulum 2013.

\section{METODE}

Penelitian ini menggunakan pendekatan kualitatif dengan analisis konten. Penelitian ini bertujuan memahami muatan penalaran dan pembuktian matematis. Dokumen yang dianalisis adalah buku teks Pelajaran Matematika SMA Kelas X Kurikulum 2013 edisi revisi 2016 yang diterbitkan oleh Pusat 


\section{Jurnal Riset Pendidikan Matematika, 6 (1), 2019 - 5}

Tria Utari, Hartono Hartono

Kurikulum dan Perbukuan Balitbang Kementrian Pendidikan dan Kebudayaan Republik Indonesia. Penelitian ini merupakan penelitian analisis konten yang sumber data penelitiannya berupa dokumen sehingga dalam pengkajiannya tidak dibatasi oleh lokasi tertentu.

Data pada penilitian ini diambil dengan meniliti subjek dan objek penelitian. Subjek penelitian ini berupa dokumen yang dianalisis, yakni buku teks Pelajaran Matematika SMA Kelas X Kurikulum 2013 Edisi Revisi 2016 yang diterbitkan oleh Pusat Kurikulum dan Perbukuan Balitbang Kementrian Pendidikan dan Kebudayaan Republik Indonesia pada tahun 2016. Pemilihan buku tersebut sebagai subjek penelitian didasarkan pada standar kelayakan oleh Badan Standar Nasional Pendidikan (BSNP) yang menyatakan bahwa buku induk yang dipakai untuk siswa SMA kelas X adalah buku yang diterbitkan oleh Pusat Kurikulum dan Perbukuan Balitbang Kementerian Pendidikan dan Kebudayaan. Objek penelitian yang digunakan adalah muatan penalaran dan pembuktian matematis.

Teknik pengumpulan data dalam penelitian ini adalah pembacaan dan pencatatan yang cermat terhadap buku teks. Instrumen utama yang digunakan dalam penelitan ini adalah human instrument yaitu peneliti sendiri. Pengetahuan, ketelitian, dan kekritisan peneliti dalam mencari dan menggali untuk menemukan data-data yang diperlukan sesuai dengan permasalahan penelitian. Peneliti menggunakan instrumen tabel data, untuk memudahkan proses kategorisasi data. Instrumen yang digunakan dalam penelitian ini adalah pedoman analisis dan lembar analisis dokumen yang disusun berdasarkan landasan teori tentang muatan penalaran dan pembuktian matematis.

Muatan penalaran dan pembuktian matematis pada penelitian ini ialah materi pembelajaran dan soal evaluasi yang mengarahkan siswa untuk membaca dan membuat justifikasi, membuat dan menyelidiki konjektur matematika, mengembangkan dan mengevaluasi pernyataan dan bukti matematika, menemukan contoh penyangkal, dan memperbaiki pembuktian yang salah.

Kisi-kisi instrumen analisis muatan penalaran dan pembuktian matematis dibagi menjadi dua aspek yakni materi pembelajaran dan soal evaluasi. Untuk aspek materi pembelajaran, indikator muatan penalaran dan pembuktiannya terdiri atas lima butir yakni (1) Sifat-sifat dan konjektur dijustifikasi dengan argumen umum, (2) Sifat-sifat dan konjektur dijustifikasi dengan argumen khusus, (3) Sifatsifat dan konjektur dijustifikasi sebagian, sebagian ditinggalkan untuk tugas siswa, (4) Justifikasi sifatsifat dan konjektur ditinggalkan untuk dikerjakan siswa, (5) Tidak ada justifikasi yang disediakan dan tidak ada pesan bahwa siswa diminta untuk menjustifikasi.

Untuk aspek soal evaluasi, indikator muatan penalaran dan pembuktiannya terdiri atas enam butir, yakni: (1) Siswa diminta untuk membuat suatu pola untuk menghasilkan konjektur, (2) Siswa diminta untuk menentukan apakah suatu konjektur benar atau salah dan menyertakan alasannya, (3) Siswa diminta menulis bukti dari suatu pernyataan, (4) Siswa diminta menentukan apakah suatu argumen benar atau salah, (5) Siswa diminta menemukan contoh penyangkal dari suatu pernyataan untuk membuktikan suatu pernyataan itu salah, (6) Siswa diminta memperbaiki pembuktian yang salah.

Pengamatan awal dilakukan untuk mengetahui jumlah sifat dan konjektur yang terdapat pada buku teks khususnya di bagian materi pembelajaran (Tabel 1). Jumlah soal evaluasi pada buku teks diketahui dengan menghitung jumlah soal pada uji kompetensi. Sifat, konjektur dan soal ini kemudian menjadi fokus pengkodean data.

Tabel 1. Jumlah Sifat, Konjektur dan Soal yang Dianalisis per Materi

\begin{tabular}{lrrr}
\hline \multicolumn{1}{c}{ Materi } & Sifat & Konjektur & Soal \\
\hline Persamaan dan Pertidaksamaan Nilai Mutlak Linear Satu Variabel & 5 & 2 & 16 \\
Sistem Persamaan Linear Tiga Variabel & 0 & 1 & 20 \\
Fungsi & 7 & 1 & 24 \\
Trigonometri & 7 & 3 & 51 \\
Jumlah & 19 & 7 & 111 \\
\hline
\end{tabular}

\section{Keabsahan Data}

Keabsahan data dalam penelitian ini didasarkan pada validitas dan reliabilitas. Validitas yang digunakan dalam penelitian ini adalah validitas semantik (semantic validity) (Kripendorff, 2004, p.323). Validitas semantik dibuktikan dengan cara melihat kesesuaian data dan dimaknai sesuai konsepnya oleh ahli. Validasi instrumen dan data dilakukan dengan pengecekan/pemeriksaan oleh ahli (expert judgement). Expert judgement instrumen pada penelitian ini dilakukan oleh dua orang ahli. 


\section{Jurnal Riset Pendidikan Matematika, 6 (1), 2019 - 6}

Tria Utari, Hartono Hartono

Reliabilitas yang digunakan dalam penilitian ini adalah stabilitas (stability) dan reproduktabilitas (reproducibility). Reliabilitas stabilitas dilakukan dengan cara mencermati kembali sumber data yang tersedia secara berulang-ulang untuk mendapatkan pemahaman yang konsisten terhadap data yang berhubungan dengan aspek yang diteliti (Kripendorff, 2004, p.215) proses tidak berubah dari waktu ke waktu. Reliabilitas stabilitas disebut sebagai intracoder reability, karena data yang dibandingkan adalah data dari coder yang sama (Eriyanto, 2011, p.285). Pada penelitian ini, pencermatan sumber dilakukan peneliti sebanyak empat kali.

Reliabilitas reproduktabilitas dilakukan dengan cara diskusi dan konfirmasi dengan teman sejawat, yaitu dua atau lebih individu, bekerja independen satu sama lain, menerapkan instruksi recording yang sama dengan unit yang sama dari analisis (Kripendorff, 2004, p.215). Reliabilitas reproduktabilitas disebut dengan intercoder reability atau interater (Eriyanto, 2011, p.286)

\section{Teknik Analisis Data}

Teknik analisis data yang digunakan pada penelitian ini adalah skema analisis isi menurut Kripendorff (2004, p.83). Pada tahap pengumpulan data, yang dimaksud unit adalah membedakan sistematis data yang dianalisis sesuai dengan pertanyaan penelitian yang telah dibuat. Kegiatan unitizing dalam penelitian ini dilakukan dengan menentukan tiga jenis unit, yakni sampling units, recording units dan context unit. Sampling units merupakan unit yang dibedakan untuk pencantuman eksklusif dalam suatu analisis (Kripendorff, 2004, p.98). Sampling units dalam penelitian ini ialah buku teks Pelajaran Matematika SMA Kelas X Kurikulum 2013. Recording units merupakan unit yang dibedakan untuk memisahkan deskripsi, transkripsi, pencatatan atau pengkodean (Kripendorff, 2004, p.99). Recording units dalam penelitian ini adalah materi dan soal evaluasi. Context unit merupakan unit terkait hal tekstual yang mengatur batasan informasi yang dipertimbangkan dalam pendeskripsian recording units (Kripendorff, 2004, p.101). Context unit dalam penelitian ini ialah muatan penalaran dan pembuktian matematis.

Penentuan sampel pada penelitian ini dilakukan dengan metode purposive sampling (Eriyanto, 2011, p.147). Pemilihan buku teks Pelajaran Matematika SMA Kelas X Kurikulum 2013 Edisi Revisi 2016 yang diterbitkan oleh Pusat Kurikulum dan Perbukuan Balitbang Kementrian Pendidikan dan Kebudayaan Republik Indonesia pada tahun 2016 sebagai subjek penelitian didasarkan pada standar kelayakan oleh BSNP yang menyatakan bahwa buku induk yang dipakai untuk siswa SMA kelas X adalah buku yang diterbitkan oleh Pusat Kurikulum dan Perbukuan Balitbang Kemdikbud.

Setelah sampel ditentukan, penelitian dilanjutkan dengan pencatatan dan deskripsi terhadap konten buku yang berkaitan dengan muatan penalaran dan pembuktian.Pencatatan dilakukan dengan mengutip bagian dalam buku yang sesuai dengan indikator yang telah dibuat sebelumnya dan mentabulasi ke dalam lembar analisis.

Catatan dan deskripsi yang dihasilkan dari tahapan sebelumnya kemudian direduksi. Reduksi data pada penelitian ini dilakukan selama tahap analisis data. Reduksi dilakukan lebih kepada penyusunan secara sistematis untuk memunculkan pola dan dikaitkan dengan menyesuaikan aspek-aspek yang tercantum pada pertanyaan penelitian.

Penarikan kesimpulan dilakukan dengan menganalisa data lebih dalam dengan mencari makna data. Penyimpulan menjembatani data deskriptif dengan pemaknaan. Penyimpulan dilakukan dengan berdasarkan konstruk analisis yang ada. Konstruksi analitis yang digunakan adalah representasi, yang biasa digunakan dalam analisis wacana. Penelitian ini menggunakan representasi sesuai analisis buku teks, yaitu dengan memetakan hasil reduksi untuk memperoleh jawaban atas pertanyaan untuk disimpulkan.

Tahap akhir dari penelitian ini ialah membuat narasi. Narasi merupakan deskripsi yang berisi jawaban pertanyaan penelitian. Narasi juga berisi informasi-informsi penting. Informasi ini bertujuan memaparkan data hasil penelitian sesuai dengan teori. Deskripsi dilakukan dengan mengkaji hasil analisis dengan sumber-sumber yang sesuai.

\section{HASIL DAN PEMBAHASAN}

Secara keseluruhan terdapat 26 sifat dan konjekur dalam buku ini. Sifat ataupun konjektur paling sedikit terdapat pada materi Sistem Persamaan Linear Tiga Variabel. Tabel 2 memperlihatkan persentase muatan penalaran dan pembuktian pada materi dalam buku teks matematika kelas X Kurikulum 2013 
edisi revisi 2016. Dari 26 sifat dan konjektur tersebut 84,6\% dilengkapi dengan justifikasi. Persentase justifikasi yang menggunakan argumen umum tidak jauh berbeda dengan persentase justifikasi yang menggunakan argumen khusus. Siswa mendapatkan kesempatan melakukan justifikasi penuh sebanyak 7,69\%. Sedangkan 7,69\% sifat dan konjektur tidak dijustifikasi sama sekali sehingga siswa tidak berkesempatan membaca justifikasi ataupun melakukan justifikasi pada sifat tersebut.

Tabel 2. Hasil Analisis Muatan Penalaran dan Pembuktian Matematis pada Bagian Materi Pembelajaran

\begin{tabular}{|c|c|c|c|c|c|c|}
\hline & Materi & $\begin{array}{c}\text { Persamaan dan } \\
\text { Pertidaksamaan } \\
\text { Nilai Mutlak } \\
\text { Linear Satu } \\
\text { Variabel }\end{array}$ & $\begin{array}{c}\text { Sistem } \\
\text { Persamaan } \\
\text { Linear Tiga } \\
\text { Variabel }\end{array}$ & Fungsi & Trigonometri & Total \\
\hline \multicolumn{2}{|c|}{$\begin{array}{l}\text { Jumlah sifat dan konjektur yang terdapat } \\
\text { pada materi }\end{array}$} & 7 & 1 & 8 & 10 & 26 \\
\hline \multirow{5}{*}{$\begin{array}{l}\text { Kategori } \\
\text { Justifikasi Sifat } \\
\text { dan Konjektur } \\
(\%)\end{array}$} & $\begin{array}{l}\text { Menggunakan argumen } \\
\text { umum (U) }\end{array}$ & $42.9 \%$ & $100 \%$ & $0 \%$ & $50 \%$ & $34.62 \%$ \\
\hline & $\begin{array}{l}\text { Menggunakan argumen } \\
\text { khusus (S) }\end{array}$ & $14 \%$ & $0 \%$ & $75 \%$ & $10 \%$ & $30.77 \%$ \\
\hline & Dijustifikasi sebagian (JS) & $14 \%$ & $0 \%$ & $25.0 \%$ & $20 \%$ & $19.23 \%$ \\
\hline & Menjadi tugas siswa (TS) & $28.6 \%$ & $0 \%$ & $0 \%$ & $0 \%$ & $7.69 \%$ \\
\hline & Tidak dijustifikasi (TP) & $0 \%$ & $0 \%$ & $0 \%$ & $20 \%$ & $7.69 \%$ \\
\hline \multicolumn{2}{|c|}{ Sifat dan konjektur yang dijustifikasi (\%) } & $71.4 \%$ & $100.0 \%$ & $100.0 \%$ & $80.0 \%$ & $84.6 \%$ \\
\hline
\end{tabular}

Sifat atau konjektur yang disajikan dengan argumen umum dapat membantu siswa mempelajari pembuktian formal. Gambar 1 merupakan salah satu temuan konjektur yang dijustifikasi dengan argumen umum.

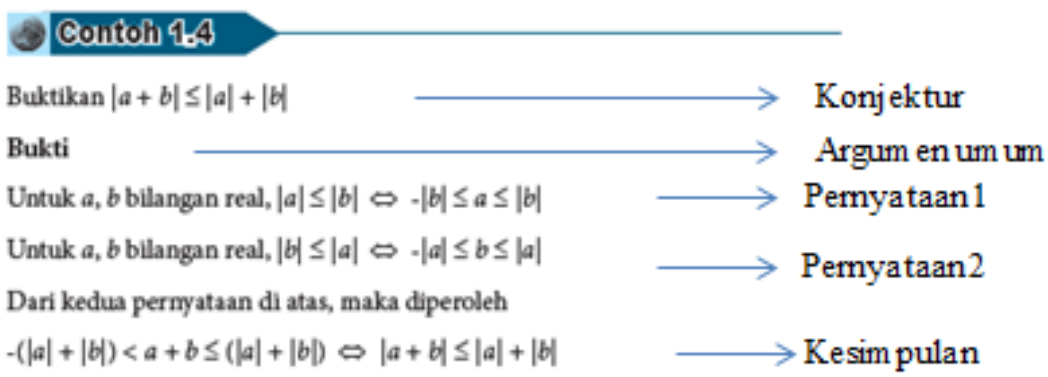

Gambar 1. Justifikasi menggunakan argumen umum untuk konjektur

Konjektur yang disajikan yaitu $|a+b| \leq|a|+|b|$. Penyajian justifikasi konjektur ini potensial memberikan kesempatan bagi siswa untuk membaca dan memahami pembuktian formal. Dengan membaca justifikasi secara seksama siswa dapat mempelajari penalaran deduktif. Sifat atau konjektur yang disajikan dengan argumen khusus dapat membantu siswa menuju tahapan pembuktian formal (Gambar 2).

Model justifikasi ini potensial memberikan kesempatan kepada siswa dalam memahami cara menggunakan generalisasi matematis, dimana argumen 1 dan 2 membentuk kesamaan yang menghasilkan generalisasi berupa sifat 3.2. Dengan membaca dan memahami secara seksama serta mengikuti petunjuk yang diberikan oleh guru, siswa mendapatkan kesempatan untuk menalar secara induktif. Sifat atau konjektur yang penjustifikasiannya ditugaskan kepada siswa, memberikan kesempatan bagi siswa untuk mengembangkan argument (Gambar 3).

Penugasan justifikasi ini tidak seutuhnya diserahkan kepada siswa tanpa petunjuk. Selain diberikan petunjuk langkah-langkah seperti pada Gambar 3 juga dibutuhkan bimbingan dari guru saat pembelajaran dalam kelas.

Hasil penelitian yang telah dijabarkan menunjukkan bahwa peluang siswa untuk mempelajari penalaran dan pembuktian matematis dengan membaca justifikasi yang disediakan cukup besar. Osterholm (2005, p.325) menyatakan bahwa aktivitas membaca dan memahami bacaan memiliki peran penting dalam pendidikan matematika. Lebih besarnya persentase sifat dan konjektur yang dilengkapi justifikasi dibandingkan persentase sifat dan konjektur yang penjustifikasiannya menjadi tugas siswa 


\section{Jurnal Riset Pendidikan Matematika, 6 (1), 2019 - 8}

Tria Utari, Hartono Hartono

menunjukkan bahwa kesempatan siswa membaca dan memahami argumen lebih besar dibandingkan kesempatan siswa membuat argumen itu sendiri.

\section{Conitoli 3.6}

Diketahui fungsi $f: \boldsymbol{R} \rightarrow \boldsymbol{R}$ dengan $f(x)=5 x-7$ dan fungsi identitas I: $\boldsymbol{R} \rightarrow \boldsymbol{R}$ dengan $I(x)=x$. Tentukanlah

a) rumus fungsi komposisi $f_{0} I$ dan $I \circ f$.

Konjektur:

b) apakah $f \circ I=I \circ f=f$. Selidikilah.<smiles>[Tl]</smiles>

$$
f^{\circ} I=I^{\circ} f=f
$$

\section{Alternatif Penyelesaian}

a) Rumus fungsi komposisi $f \circ I$ dan $I$ of

$$
\checkmark(f \circ I)(x)=f(I(x))
$$

$=f(x)$

$$
=5 x-7
$$

$\checkmark(\operatorname{lof})(x)=I(\mathcal{R}(x))$

$=I(f(x))$

$$
=5 x-7
$$

b) Berdasarkan hasil pada butir (a) maka dapat disimpulkan bahwa $f \circ I=I \circ f=f$

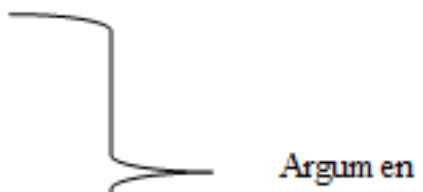

Berdasarkan penyelesaian Contoh 3.6 diperoleh sifat berikut.

\section{Sifat 3.2}

Diketahui $f$ suatu fungsi dan $I$ merupakan fungsi identitas. Jika $R_{\rho} D_{f} \neq \emptyset$, maka terdapat sebuah fungsi identitas, yaitu $I(x)=x$, sehingga berlaku sifat identitas, yaitu

$$
f o l=I \text { lof }=f
$$

Gambar 2. Justifikasi menggunakan argumen khusus untuk sifat 3.2

Dapatkah kamu memberikan pendapatmu tentang hubungan $|x|$ dengan $\sqrt{x^{2}}$ ? Sebelum kamu menjawab, kamu coba lakukan pengamatan pada tabel berikut dan ikuti langkah-langkahnya.

Langkah 1. Lengkapi Tabel 1.5. Tentukan hubungan antara $|x|$ dengan $\sqrt{x^{2}}$ dengan melakukan pengamatan pada tabel yang telah dilengkapi.

Tabel 1.5 Hubungan $\sqrt{x^{2}}$ dan $|x|$

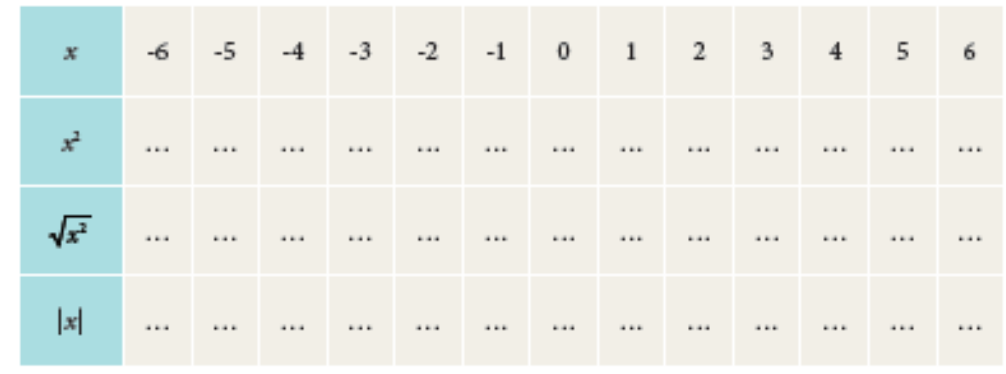

Langkah 2. Lakukan pengamatan pada nilai di tabel. Nilai baris manakah yang sama nilainya?

Langkah 3. Ambillah kesimpulanmu tentang hubungan antara $\sqrt{x^{2}}$ dan $|x|$.

Gambar 3. Penugasan Justifikasi Sifat "Hubungan Harga Mutlak x dengan Akar x Kuadrat" 


\section{Jurnal Riset Pendidikan Matematika, 6 (1), 2019 - 9}

Tria Utari, Hartono Hartono

Persentase justifikasi yang menggunakan argumen umum tidak jauh berbeda dengan persentase justifikasi yang menggunakan argumen khusus, hal ini menujukkan bahwa level justifikasi yang dipelajari siswa seimbang antara argumen umum maupun khusus. Artinya, siswa tetap dipermudah dengan bacaan non formal, namun tetap disediakan bacaan formal yang bermanfaat untuk meningkatkan kemampuan siswa dalam matematika yang dituntut semakin formal dalam setiap pertambahan jenjangnya. Movshovitz Hadar dalam Thompson, Senk \& Johnson, (2012, p.282) menjelaskan bahwa reasoning about specific case is a helpful pedagogical step in generating a general argument.

Dalam memperhatikan matematika secara keilmuan yang murni, keberadaan justifikasi yang menggunakan argumen umum akan sangat baik untuk mengembangkan cara siswa berpikir formal. Di lain sisi, dalam memperhatikan matematika dari sisi matematika sekolah, keberadaan justifikasi yang menggunakan argumen khusus akan sangat baik untuk membantu siswa untuk memahami argumen umum itu sendiri. Artinya, sulit untuk mengatakan mana yang lebih baik diantara justifikasi menggunakan argumen umum atau argument khusus. Penyajian sifat atau konjektur yang dijustifikasi baik dengan argumen umum maupun argumen khusus memberikan kesempatan bagi siswa untuk membaca dan memahami pembuktian matematis. Weber \& Mejia-Ramos (2011, p.331) menyatakan bahwa pemahaman terhadap suatu argumen dapat terjadi ketika siswa membaca bukti di dalam buku teks.

Meskipun justifikasi telah tersedia dalam buku, namun siswa perlu untuk tetap diarahkan agar mengerti bahwa justifikasi tersebut bertujuan menyimpulkan sifat dan konjektur. Disinilah peran guru sebagai mediator dibutuhkan. Sebagaimana tercantum dalam Buku Guru Matematika SMA Kelas X Kurikulum 2013 Edisi Revisi 2016 yang diterbitkan oleh Pusat Kurikulum dan Perbukuan Balitbang Kementrian Pendidikan dan Kebudayaan Republik Indonesia bahwa peran guru adalah sebagai mediator dengan membantu mengarahkan dan membimbing siswa dalam pembelajaran.

Penelitian ini juga melihat kesempatan siswa mengembangkan kemampuan penalaran dan pembuktian matematis dalam soal yang disajikan pada uji kompetensi (Tabel 3).

Tabel 3. Hasil Analisis Muatan Penalaran dan Pembuktian Matematis pada Bagian Soal Evaluasi

\begin{tabular}{|c|c|c|c|c|c|c|}
\hline \multicolumn{2}{|l|}{ Materi } & $\begin{array}{c}\text { Persamaan dan } \\
\text { Pertidaksamaan } \\
\text { Nilai Mutlak } \\
\text { Linear Satu } \\
\text { Variabel }\end{array}$ & $\begin{array}{c}\text { Sistem } \\
\text { Persamaan } \\
\text { Linear Tiga } \\
\text { Variabel }\end{array}$ & Fungsi & Trigonometri & Total \\
\hline \multicolumn{2}{|c|}{ Jumlah Soal } & 16 & 20 & 24 & 51 & 111 \\
\hline $\begin{array}{l}\text { Indikator Soal } \\
\text { Penalaran dan }\end{array}$ & $\begin{array}{l}\text { Membuat konjektur } \\
\text { (MK) }\end{array}$ & $0 \%$ & $0 \%$ & $4.17 \%$ & $0 \%$ & $0.9 \%$ \\
\hline \multirow[t]{5}{*}{ Pembuktian } & $\begin{array}{l}\text { Mengidentifikasi } \\
\text { konjektur (IK) }\end{array}$ & $18.75 \%$ & $10 \%$ & $0 \%$ & $7.84 \%$ & $8.11 \%$ \\
\hline & $\begin{array}{l}\text { Mengembangkan } \\
\text { suatu argumen (MA) }\end{array}$ & $6.25 \%$ & $0 \%$ & $8.33 \%$ & $5.88 \%$ & $5.41 \%$ \\
\hline & $\begin{array}{l}\text { Mengevaluasi suatu } \\
\text { argumen (EA) }\end{array}$ & $0 \%$ & $0 \%$ & $0 \%$ & $0 \%$ & $0 \%$ \\
\hline & $\begin{array}{l}\text { Membuat contoh } \\
\text { penyangkal (MCP) }\end{array}$ & $12.5 \%$ & $0 \%$ & $0 \%$ & $5.88 \%$ & $4.5 \%$ \\
\hline & $\begin{array}{l}\text { Mengidentifikasi } \\
\text { suatu kesalahan (IK) }\end{array}$ & $0 \%$ & $0 \%$ & $0 \%$ & $0 \%$ & $0 \%$ \\
\hline \multicolumn{2}{|c|}{ Jumlah Soal Penalaran dan Pembuktian } & 4 & 2 & 3 & 7 & 16 \\
\hline \multicolumn{2}{|c|}{$\begin{array}{l}\text { Persentase soal Penalaran dan } \\
\text { Pembuktian }\end{array}$} & $25 \%$ & $10 \%$ & $12.5 \%$ & $13.73 \%$ & $14.41 \%$ \\
\hline
\end{tabular}

Dari keseluruhan soal pada uji kompetensi $14.41 \%$ yang merupakan soal penalaran dan pembuktian matematis dengan persentase terbanyak pada materi Persamaan dan Pertidaksamaan Nilai Mutlak Satu Variabel. Mengidentifikasi konjektur merupakan indikator soal penalaran dan pembuktian terbanyak yang ditemukan dalam buku. Kompetensi dasar yang diharapkan dalam standar isi pada Peraturan Menteri Pendidikan dan Kebudayaan Republik Indonesia Nomor 21 Tahun 2016 yakni menjelaskan pola dan menggunakannya untuk melakukan prediksi dan kecenderungan jangka panjang (dalam penelitian ini disebut membuat konjektur) termuat $0,9 \%$ di dalam buku, bahkan kompetensi yang lain yakni memeriksa kesahihan argumen (dalam penelitian ini disebut mengevaluasi suatu argumen) 
tidak ditemukan sama sekali dalam buku (Menteri Pendidikan dan Kebudayaan Republik Indonesia, 2016).

Soal dengan indikator menjelaskan pola dan menggunakannya untuk melakukan prediksi dan kecenderungan jangka panjang ditemukan satu pada materi Fungsi (Gambar 4).

7. Jika $f$ fungsi yang memenuhi persamaan $f(1)=4$ dan $f(x+1)=2 f(x)$.

Tentukanlah $f(2014)$.

\section{Gambar 4. Soal Nomor 7 Uji Kompetensi 3.1}

Secara eksplisit, soal (Gambar 4) ini tidak menunjukkan perintah untuk membuat konjektur, namun, secara implisit soal ini potensial memberikan kesempatan kepada siswa untuk menemukan pola dan membuat konjektur. Soal ini memberikan kesempatan kepada siswa untuk menalar secara induktif.

Membuat contoh penyangkal dan mengidentifikasi suatu kesalahan merupakan indikator yang tak kalah penting dalam penalaran dan pembuktian matematis. Shumway \& Lester (1974, p.210) menyimpulkan dari hasil penelitiannya bahwa "negative instances are important in the learning of concepts". Hal ini berarti siswa membutuhkan aktivitas terkait memahami contoh yang salah dan mengidentifikasi kesalahan itu sendiri untuk mempelajari konsep. Namun, persentase soal dalam buku dengan indikator membuat contoh penyangkal dan mengidentifikasi suatu kesalahan sangat kecil sekali. $4,5 \%$ soal dalam buku masuk indikator membuat contoh penyangkal. Sementara, soal dengan indikator mengidentifikasi kesalahan tidak ditemukan sama sekali.

Soal dengan indikator membuat contoh penyangkal ditemukan implisit dalam soal yang dimaksudkan untuk indikator mengidentifikasi konjektur. Gambar 5 merupakan salah satu temuan soal tersebut dalam buku.

2. Manakah pernyataan berikut ini yang merupakan pernyataan bernilai benar? Berikan alasanmu.

a) $|k|=k$, untuk setiap $k$ bilangan asli.

b) $|x|=x$, untuk setiap $x$ bilangan bulat.

c) Jika $|x|=-2$, maka $x=-2$.

d) Jika $2 t-2>0$, maka $|2 t-2|=2 t-2$.

e) Jika $|x+a|=b$, dengan $a, b, x$ bilangan real, maka nilai $x$ yang memenuhi hanya $x=b-a$.

f) Jika $|x|=0$, maka tidak ada $x$ bilangan real yang memenuhi persamaan.

g) Nilai mutlak semua bilangan real adalah bilangan non negatif.

Gambar 5. Soal No. 2 Uji Kompetensi 1.1.

Konjektur pada soal (Gambar 5) ini merupakan pernyataan matematis pada setiap butir soal yang masih harus dibuktikan kebenarannya. Cara untuk mengidentifikasi konjektur ini bisa dengan menggunakan argumen umum maupun menggunakan argumen khusus yakni dengan contoh penyangkal.

Soal yang tidak kalah penting dari soal yang lain adalah soal dengan indikator mengembangkan argument (Gambar 6). Gambar 6 merupakan salah satu temuan soal tersebut dalam buku:

7. Perhatikan segitiga siku-siku di bawah ini.

Tunjukkan bahwa

a) $(\sin A)^{2}+(\cos A)^{2}=1$

b) $\tan B=\frac{\sin B}{\cos B}$

c) $(\operatorname{scs} A)^{2}-(\cot A)^{2}=1$

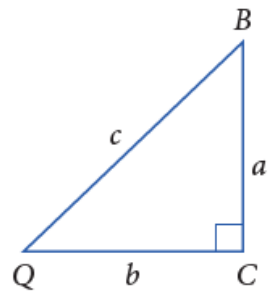

Gambar 6. Soal Nomor 7 Uji Kompetensi 4.2 
Dalam membuat argumen ini, siswa berkesempatan melakukan pembuktian langsung yakni dengan menggunakan argumen umum. Kegiatan ini memberikan kesempatan kepada siswa untuk menalar secara deduktif. Kesempatan siswa untuk melakukan pembuktian secara langsung termuat secara implisit, karena tidak ada kata atau kalimat pada soal yang mengarahkan kepada hal tersebut.

Penelitian terkait analisis soal pada buku teks matematika juga pernah dilakukan sebelumnya oleh Rufiana (2015) yang menunjukkan bahwa persentase soal penalaran dan pembuktian pada buku teks Matematika kelas VII Kurikulum 2013 sangat rendah yakni 1,45\% saja. Dengan melihat hasil analisis pada buku teks matematika kelas VII (Rufiana, 2015) dan kelas X (penelitian ini) dapat dilihat bahwa persentase soal penalaran dan pembuktian masih sangat kecil. Hal ini mengakibatkan bahwa pengalaman siswa terhadap soal penalaran dan pembuktian juga sangat sedikit.

Dari uraian tersebut, kita dapat menyimpulkan bahwa muatan penalaran dan pembuktian matematis dalam buku teks pelajaran Matematika SMA Kelas X Kurikulum 2013 Edisi Revisi 2016 yang diterbitkan oleh Pusat Kurikulum dan Perbukuan Balitbang Kementrian Pendidikan dan Kebudayaan Republik Indonesia dominan pada bagian materi pembelajaran namun masih kurang pada bagian soal evaluasi. Artinya, kesempatan siswa untuk mempelajari penalaran dan pembuktian melalui membaca teks (dalam hal ini justifikasi) lebih besar dibandingkan kesempatan siswa untuk mempelajari penalaran dan pembuktian melalui pengerjaan soal.

Tabel 3 memperlihatkan persentase muatan penalaran dan pembuktian pada soal dalam buku teks matematika kelas X Kurikulum 2013 edisi revisi 2016. Dari 111 soal tersebut 14,41\% merupakan soal penalaran dan pembuktian. Beberapa soal masuk ke dalam lebih dari satu indikator. Tidak terdapat soal yang masuk dalam indikator mengidentifikasi konjektur maupun mengidentifikasi suatu kesalahan.

\section{SIMPULAN}

Berdasarkan hasil penelitian dan pembahasan dapat disimpulkan bahwa pada bagian materi pembelajaran $84,6 \%$ sifat dan konjektur disajikan lengkap dengan justifikasi, 7,69\% sifat dan konjektur ditugaskan kepada siswa untuk dijustifikasi, 7,69\% sifat dan konjektur tidak dijustifikasi sama sekali. Artinya, muatan penalaran dan pembuktian matematis pada bagian materi pembelajaran memberikan kesempatan besar bagi siswa untuk menalar dan membuktikan melalui membaca justifikasi, namun memberikan kesempatan yang kecil melalui pengembangan justifikasi.

Pada soal evaluasi $14,41 \%$ soal yang merupakan soal penalaran dan pembuktian. Soal dengan indikator mengidentifikasi konjektur menjadi soal yang paling dominan ditemukan. Sementara, soal dengan indikator mengidentifikasi suatu kesalahan tidak ditemukan sama sekali. Artinya, muatan penalaran dan pembuktian matematis pada soal evaluasi belum sepenuhnya memberikan kesempatan bagi siswa untuk menalar dan membuktikan melalui pengerjaan soal.

Pengembang kurikulum dan penulis buku teks mata pelajaran matematika diharapkan lebih memperhatikan muatan penalaran dan pembuktian matematis pada buku teks khususnya pada soal evaluasi dengan memperbanyak jenis soal penalaran dan pembuktian berdasarkan indikatornya. Selanjutnya, perlu diperbanyak tagihan kerja terkait penalaran dan pembuktian matematis agar perhatian siswa terhadap hal tersebut juga bertambah.

\section{DAFTAR PUSTAKA}

Eriyanto, E. (2011). Analisis isi: Pengantar metodologi untuk penelitian ilmu komunikasi dan ilmu-ilmu sosial lainnya. Jakarta: PT Fajar Interpratama Mandiri.

Fithriyyati, N., \& Maryani, I. (2018). Science lesson plan evaluation for 7th grade secondary school: A learning process reflection. Psychology, Evaluation, and Technology in Educational Research, 1(1), 9-18. doi:http://dx.doi.org/10.33292/petier.v1i1.17

Habsah, F. (2017). Developing teaching material based on realistic mathematics andoriented to the mathematical reasoning and mathematical communication. Jurnal Riset Pendidikaan Matematika, 4(1), 43-55. doi:https://doi.org/10.21831/jrpm.v4i1.10199

Kripendorff, K. (2004). Content analysis: an introduction to its methodology, ( $\left.2^{\text {nd }} \mathrm{ed}\right)$. Thousand Oaks, CA: Sage Publication.

Menteri Pendidikan dan Kebudayaan Republik Indonesia. (2016). Peraturan Menteri Pendidikan dan Kebudayaan Nomor 8, Tahun 2016, tentang standar isi pendidikan dasar dan menengah. 
Menteri Pendidikan dan Kebudayaan Republik Indonesia. (2016). Peraturan Menteri Pendidikan dan Kebudayaan Nomor 21, Tahun 2016, tentang Standar Isi Pendidikan Dasar dan Menengah.

Menteri Pendidikan Nasional Republik Indonesia. (2005). Peraturan Menteri Pendidikan Nasional Republik Indonesia Nomor 11, Tahun 2005, tentang buku.

Menteri Pendidikan Nasional Republik Indonesia. (2008). Peraturan Menteri Pendidikan Nasional RI Nomor 2, Tahun 2008, tentang Buku.

National Council of Teacher of Mathematics. (2000). Principles and standards for school mathematics. Reston, VA: Author.

National Council of Teacher of Mathematics. (2009). Focus in high school mathematics: Reasoning and sense making. Retrieved from http://goo.gl/M9GiWU

OECD. (2013). PISA 2012 assessment and analytical framework: Mathematics, reading, science, problem solving and financial literacy. Paris: OECD Publishing.

OECD. (2014). PISA 2012 results: What student know and can do, Students performance in mathematics, reading and science (volume 1). Paris: OECD Publishing.

OECD. (2015). PISA 2015 draft mathematics framework. Paris: OECD Publishing.

Olson, M. H., \& Hergenhahn, B. R. (2012). Theories of learning ( $7^{\text {th }}$ ed.) (T. Wibowo BS, Trans.). Jakarta: Kencana Prenada Media Group.

Ontario. (2005). The ontario curriculum grades 1-8 mathematics. Retrieved from http://www.edu.gov.on.ca/eng/curriculum

Osterholm, M. (2005). Characterizing reading comprehension of mathematical texts. Educational Studies in Mathematics. 63(3), 325-346. https://doi.org/10.1007/s10649-005-9016-y

Pusat Perbukuan Departemen Pendidikan Nasional. (2005). Pedoman penilaian buku pelajaran matematika untuk sekolah menengah pertama dan sekolah menengah atas. Jakarta: Departemen Pendidikan Nasional.

Reiss, K. M., Heinze, A., Renkel, A., \& Grob, C. (2008). Reasoning and proof in geometry: Effects of a learning environtment based on heuristic worked-out examples. Journal of ZDM Mathematics Education, 40(3), 455-467. https://doi.org/10.1007/s11858-008-0105-0

Rufiana, I. (2016). Level kognitif soal pada buku teks matematika kurikulum 2013 kelas VII untuk pendidikan menengah. Jurnal Dimensi Pendidikan dan Pembelajaran, 2(2), 13-22. doi:http://dx.doi.org/10.2426/dpp.v2i2.153

Shumway, R. J., \& Lester, F. K. (1974). Negative instances and the acquisition of the mathematical concepts of commutativity and associativity. Journal for Research in Mathematics Education, 5(3), 218-227. https://doi.org/10.1007/BF01424552

Stacey, K., \& Vincent, J. (2009). Modes of reasoning in explanations in Australian eighth-grade mathematics textbooks. Education Study Mathematic, 72(3), 271-288. https://doi.org/10.1007/s10649-009-9193-1

Stylianides, A. J., \& Stylianides, G. J. (2006). Content knowledge for mathematics teaching: the case of reasoning and proving. Proceedings $30^{\text {th }}$ Conference of the International Group for the Psychology of Mathematics Education, 5, 201-208.

Thompson, D. R., Senk, L. S., \& Johnson, G. J. (2012). Oppurtunities to learn reasoning and proof in high school mathematics textbooks. Journal for Researching Mathematics Education, 43(3), 253295. https://doi.org/10.5951/jresematheduc.43.3.0253

Van de Walle, J. A. (2007). Elementary and middle school mathematics: teaching developmentally (6 $6^{\text {th }}$ ed.). Boston, MA: Pearson.

Weber, K., \& Mejia-Ramos, J. P. (2011). Why and how mathematicians read proofs: an exploratorystudy. Education Study Mathematics, 76(3), 329-344. https://doi.org/10.1007/s10649010-9292-z

Wibowo, A. (2017). Pengaruh pendekatan pembelajaran matematika realistik dan saintifik terhadap prestasi belajar, kemampuan penalaran matematis dan minat belajar. Jurnal Riset Pendidikan Matematika, 4(1), 1-10. doi:https://doi.org/10.21831/jrpm.v4i1.10066 
Jurnal Riset Pendidikan Matematika, 6 (1), 2019 - 13

Tria Utari, Hartono Hartono

Widyaharti, M., Trapsilasiwi, D., \& Fatahillah, A. (2015). Analisis buku siswa matematika kurikulum 2013 untuk kelas x berdasarkan rumusan Kurikulum 2013. KadikmA, 6(2). Retrieved from https://jurnal.unej.ac.id/index.php/kadikma/article/view/1994 